\title{
The Truman Doctrine: Turkey
}

\author{
By Joseph C. Satterthwaite
}

AbSTRACT: On February 21, 1947, the U.S. government was informed by the British government that by April 1 it would have to discontinue, because of its own difficulties, its military and economic aid to Greece and Turkey. It hoped the United States could take over this burden in both countries. President Truman and the State, War, and Navy departments at once realized that unless the United States did so, Greece would be taken over by its communist partisans strongly supported by the Soviet government working through the communist Bulgarian and Yugoslav governments; that if this happened Turkey would find itself in an untenable position in spite of its large but antiquated army; and that the eastern Mediterranean and the Near East in that event would inevitably fall under communist domination. In a dramatic message to Congress on March 12, 1947, President Truman said that the U.S. must take immediate and resolute action to support Greece and Turkey. The Congress, after extensive hearings, approved this historic change in U.S. foreign policy in a bill signed May 22, known as Public Law 75. Out of the President's message came the Truman Doctrine. The principle of assistance to countries of the free world under the threat of communist aggression having been accepted by the Congress, the Marshall Plan followed not long after. The military and economic aid given Turkey in the ensuing years was highly effective: the U.S. probably received more per dollar advanced than in any other country, at least for the period of this study - which ends with the signing of the CENTO (Baghdad) Pact in 1955 .

Joseph C. Satterthwaite was appointed a Foreign Service officer in 1926 after receiving $A . B$. and A.M. degrees from the University of Michigan. He was Secretary of Embassy in Ankara, 1940-44. In 1945 he was assigned to the Near Eastern Division of the State Department. In 1946 he was named Special Assistant to the Director for Near Eastern and African Affairs, in 1947 the Deputy Director, and from July 1948 to July 1949 he was Director for Near Eastern and African Affairs. Subsequently he served as Ambassador to Ceylon, Diplomatic Agent in Tangier for Morocco, Ambassador to Burma, Director General of the Foreign Service, Assistant Secretary of State for African Affairs, and Ambassador to South Africa. He retired from the Foreign Service at the end of 1965. Since then he has been a consultant on foreign affairs. 
$\mathrm{B}^{\mathrm{r}}$ Y A fortunate coincidence the May 1972 issue of THE AnNals will appear during the twenty-fifth anniversary of the Truman Doctrine, the subject of this article. Its scope is the genesis of that doctrine as it related to Turkey and how it worked in that country up to the signing of the Baghdad Pact in 1955.

\section{Genesis of the Truman Doctrine}

On the afternoon of Friday, February 21, 1947, the Private Secretary of the British Ambassador, Lord Inverchapel, telephoned the Secretary of State's office. He said his Ambassador had been instructed to deliver personally to the Secretary (General George C. Marshall) a communication of great importance. $\mathrm{He}$ requested an appointment for that afternoon.

As it happened the Secretary had left shortly before for Princeton, where he was to deliver an address, and would not return until Monday morning. The office of the Under Secretary, Dean Acheson, was accordingly informed. As related in Present at the Creation: $M y$ Years in the State Department, Acheson telephoned Inverchapel, who told him the British note contained very important information about a crisis in British aid to Greece. Acheson thereupon suggested that the Ambassador send his First Secretary to the Department to deliver a copy to Loy Henderson, Director of the Office of Near Eastern and African Affairs. Inverchapel could then carry out his orders by delivering the original note to the Secretary in person on Monday morning. This was done.

The First Secretary handed Henderson not one note but two. The first contained the startling information that British aid to Greece would have to end by April 1. It also described the rapidly deteriorating state of Greece's economy and security. The second note reported that the British could no longer continue their assistance to Turkey, which was maintaining the large army that Soviet pressure demanded, and that the Turks would be unable to handle the financing of both the modernization of their army and the economic development of the country. The British government hoped that the United States could take over this burden in both countries.

Acheson instructed Henderson and John D. Hickerson, Director of the Office of European Affairs (since the Soviet Union, Bulgaria, and Yugoslavia, which were under his jurisdiction, constituted the menacing threat to Greece and Turkey), to begin preparations that evening on the means to cope with the crisis with which the British note confronted us. This they did.

The next morning, Saturday, the writer-who was making preparations to head a Mission to Nepal-learned of the crisis at a meeting called by Henderson of the members of his staff most directly concerned. Henderson expressed the view that if the British withdrew their troops from Greece, and we did not intervene, the Greek communist partisans supported by Bulgaria and Yugoslavia were sure to gain control of Greece. If this happened the free world would lose the eastern Mediterranean and the Near East to the communists. Turkey, the only country in the area with an army strong enough to make the Russians hesitate, would find itself in an untenable position. Therefore the United States, by filling the gap caused by the British withdrawal, must show a greater determination to resist this communist drive than the determination of the communists to gain control of Greece. Henderson told us Acheson had informed President Truman of the crisis at once and that both, he understood, agreed with his view expressed above.

From then on the old State Department moved with unaccustomed speed 
to cope with the crisis. General Marshall returned to his office Monday morning, read the British notes and the background papers that had been prepared for him, and received Lord Inverchapel at 10:00 A.M. The Ambassador left knowing that the Secretary fully appreciated the seriousness of the notes he had handed him. The Secretary next instructed Acheson to take responsibility for action from there on, as he had to leave for Moscow in a week for the meeting of the Council of Foreign Ministers and would be fully occupied with preparations for the meeting. Acheson asked Henderson to head a team working to prepare the necessary recommendations for the President, with Hickerson as his principal assistant. They, of course, maintained liaison with the officials of the Pentagon preparing the military aspects of the action required.

After the Cabinet luncheon that Monday morning, the President met with General Marshall, Secretary of War Robert Patterson, Secretary of the Navy James Forrestal, Admiral Forrest Sherman, and General Lauris Norstad. All except the President and Marshall met with Acheson, Henderson, and Hickerson in the Under Secretary's office afterwards. "We agreed," Acheson wrote in Present at the Creation,

that the President and his principal advisers seemed convinced that it was vital to the security of the US for Greece and Turkey to be strengthened to preserve their national independence, that only the US could do this, that funds and the authority of Congress were necessary, and that State would prepare for concurrence by War and Navy specific recommendations for the President. General Marshall approving, Henderson and his staff worked with me preparing the recommendations. ${ }^{1}$

1. Dean Acheson, Present at the Creation: My Years in the State Department (New York: W. W. Norton \& Co., 1969), p. 218.
The recommendations were ready the next day and the President approved the paper for action. The next step was consultation with Congress, and the President set up a meeting for the next day.

The President, Marshall, and Acheson met the next morning with congressional leaders, headed by Senator Arthur Vandenberg of Michigan who was both Acting-President of the Senate-there being no vice-president-and Chairman of the Senate Foreign Relations Committee. He, with the President and Acheson, was to play a key role in the success of what came to be called the Truman Doctrine.

After opening remarks by the President and Secretary Marshall, Acheson made a reasoned and impassioned presentation of the seriousness of the crisis facing the United States. $\mathrm{He}$, with the full backing of the President and Marshall, was obviously successful in persuading the congressional leaders present to give their support to the proposed program for aid to Greece and Turkey. Particularly important, they persuaded Senator Vandenberg, who promised his support.

\section{Postwar Threats to Turkey from THE SOVIET UNION}

Because Greece was the danger spot, most of the ensuing discussions and statements before the congressional committees were concerned largely with that country, but always with some mention of the equal importance of aiding Turkey; so mention might be made at this point of the threats and pressures from the Soviet Union to which Turkey had been exposed following World War II.

When the writer returned to the United States in July 1945 for the first time in more than five years, he found there was a feeling among many of the friends he met while on home leave that 
the Soviet Union, our ally during the war, could be expected to co-operate with the Western world in solving grave postwar problems. Upon reporting for duty in the Division of Near Eastern Affairs in September, however, he at once learned how unrealistic that feeling was.

Thus Turkey already knew from Soviet claims on the border regions of Kars and Ardahan, and from Soviet demands for a new regime governing the Straits that would have given Russia virtual control of them, that the Soviets had no intention of letting up on these pressures, and that its only protection was to maintain its army of more than five hundred thousand men that had been mobilized since the early days of World War II.

Turkey had firmly rejected all these Soviet proposals. To the renewed Soviet proposal of July 1946 for sole control of the Straits by the Black Sea Powers, a proposal also repeated to the United States, Great Britain, and France, the Turkish government again said no, this time with the full backing of those Powers. President Truman in his Memoirs said that the answer to the Soviet Union made it clear that if the Straits should become the object of Russian aggression, "the resulting situation would constitute a threat to international security and would clearly be a matter for action on the part of the Security Council." Then Truman added:

The Turkish Government, encouraged by the American attitude, rejected the Soviet demands and showed admirable determination to resist if Russia should resort to open violence. But Turkey's army, though sizable, was poorly equipped and would have been no match for the battle-tested divisions of the Kremlin.

More serious still was the drain which this continuous exertion made on the nation's economy. Toward the close of 1946 our Ambassador reported from Ankara:
"Turkey will not be able to maintain indefinitely a defensive posture against the Soviet Union. The burden is too great for the nation's economy to carry much longer."

Thus with its experience of continuing Soviet pressures and the difficulties of modernizing its large army, Turkey found itself more than ready to welcome the assistance which the Truman Doctrine promised.

\section{President Truman's Message to Congress, March 12, 1947}

Following the President's meetings with congressional leaders, the State Department, under the guidance of Dean Acheson and Loy Henderson, mobilized all resources in drafting the required legislation and in preparing the public for what was one of the most important foreign policy decisions in our history. Joseph M. Jones, the Press Officer, was assigned to make the first draft of a message which the President proposed to deliver in person before a joint session of Congress. Acheson himself carried out the initial briefing of the press.

The Message to Congress was delivered by the President in person on March 12, 1947. So important was it, enunciating as it did what came to be known as the Truman Doctrine, that some of the paragraphs of his relatively short address need to be repeated here.

First the President described the Soviet pressures being applied to Greece and Turkey, Greece's deplorable economic situation, its state of exhaustion, and the dangers to the free world should it collapse. Then he added:

I believe it must be the policy of the US to support free peoples who are resisting attempted subjugation by armed minorities or by outside pressures.

I believe that we must assist free peoples to work out their own destinies in their own ways. 
I believe that our help should be primarily economic and financial, which is essential to economic stability and orderly political processes. . . .

In helping free and independent nations to maintain their freedom, the US will be giving effect to the Charter of the UN. . . .

Should we fail to aid Greece and Turkey in this fateful hour, the effect will be farreaching to the West as well as to the East.

We must take immediate and resolute action. $^{2}$

The relatively short part of the President's message concerning Turkey said:

The future of Turkey as an independent and economically sound state is clearly no less important to the freedom-loving peoples of the world than the future of Greece. Turkey has been spared the disasters that have beset Greece. And during the war the US and Great Britain furnished Turkey with material aid.

Nevertheless, Turkey needs our support.

Since the war Turkey has sought additional financial assistance from Great Britain and the US for the purpose of effecting that modernization necessary for the maintenance of its national integrity.

That integrity is essential for the preservation of order in the Middle East.

The British Government has informed us that, owing to its own difficulties, it can no longer extend financial or economic aid to Turkey.

As in the case of Greece, if Turkey is to have the assistance it needs, the US must supply it. We are the only country able to provide that help. . . .

The free peoples of the world look to us for support in maintaining their freedom.

If we falter in our leadership we may endanger the peace of the world and we shall surely endanger the welfare of this nation.

President Truman asked Congress, in addition to the funds requested- $\$ \mathbf{4 0 0}$ million for the period ending June 30 , 1948, for Greece and Turkey-for au-

2. Harry S Truman, Memoirs, vol. 2, Years of Trial and Hope (Garden City, N.Y.: Doubleday \& Co., 1955), pp. 97-98. thorization to detail American civilian and military personnel to Greece and Turkey, and that the instruction and training of selected Greek and Turkish personnel also be authorized.

Senator Vandenberg, speaking to reporters on the afternoon of the President's address was quoted as saying:

The President's message faces facts and so must Congress. The independence of Greece and Turkey must be preserved, not only for their own sakes, but also in defense of peace and security for all of us. In such a critical moment the President's hand must be upheld. Any other course would be dangerously misunderstood. But Congress must carefully determine the methods and explore the details in so momentous a departure from our previous policies. $^{3}$

\section{Congressional hearings}

The day after the President's address to Congress, the Senate Foreign Relations Committee began hearings on the proposed legislation. The Senate approved the bill, with amendments agreeable to the administration, on April 22 by a vote of 67 to 23 . The hearings before the House Foreign Affairs Committee began on March 20. The House approved the bill on May 8 by a vote of 287 to 107.

On May 22, 1947, President Truman signed the bill, which became known as Public Law 75. On signing it he issued a statement which said, in part:

This act authorizing US aid to Greece and Turkey, which I have just signed, is an important step in the building of peace. Its passage by overwhelming majorities in both Houses of Congress is proof that the US earnestly desires peace and is willing to make a vigorous effort to help create the conditions of peace.

The conditions of peace include, among

3. Quoted in Joseph Marion Jones, The Fifteen Weeks (February 21-June 5, 1947) (New York: Viking Press, 1955), p. 174. 
other things, the ability of nations to maintain order and independence, and to support themselves economically. In extending the aid requested by states members of the UN for the purpose of maintaining these conditions, the US is helping to further aims and purposes identical with those of the UN. Our aim in this instance is evidence not only that we pledge our support to the UN but that we act to support it.

The references to the United Nations in this statement no doubt were inspired by the fact that the strongest opposition to the draft that developed in Congress was because it seemed to many members to bypass the United Nations. For this reason our representative to the United Nations, Ambassador Warren Austin, was instructed to make a statement assuring that body that this was not the intent of the bill. Then Senator Vandenberg gained support for the bill with his amendment, which was accepted, instructing the President to withdraw all aid if the Security Council or the General Assembly found that U.N. action had made the aid undesirable.

So, with the adoption of PL 75 on May 22 by the President's signature, the Truman Doctrine became the law of the land. He explains it in his Memoirs thus:

I wished to state, for all the world to know, what the position of the US was in the face of the new totalitarian challenge. This declaration of policy soon began to be referred to as "The Truman Doctrine." This was, I believe, the turning point in America's foreign policy, which now declared that wherever aggression, direct or indirect, threatened the peace, the security of the US was involved.4

Implementation OF THE TURKISH Aid Program

Little time was lost in implementing PL 75. A preliminary survey of Tur-

4. Truman, Years of Trial and Hope, pp. 105-6. key's military needs was organized by the Pentagon in May. .It completed its survey in July.

But before an aid mission could be sent to Turkey, it was necessary to negotiate an aid agreement under the terms of PL 75. Although the Turks fully welcomed the prospect of our aid, certain stipulations of that law caused them some difficulty because of their bitter memories of the history of the capitulations in Turkey. Fortunately, our Ambassador to Turkey, Edwin C. Wilson, who carried on the negotiation with the Turkish Foreign Minister, Hasan Saka, was exceptionally able and experienced. The Turks' objection to use of the word administrator was solved by naming the Ambassador chief of the mission, with the heads of the army, air force, navy, and roads groups having the title of director.

More difficult was agreeing on language which would meet the requirement in PL 75 of open access to the work of the mission not only to U.S. officials, but to the press as well. This problem was solved in the agreement signed at Ankara on July 12, 1947, by using in Article III the following language:

The Government of Turkey and the Government of the US will cooperate in assuring the peoples of the US and Turkey full information concerning the assistance furnished pursuant to this agreement. To this end, in so far as may be consistent with the security of the two countries: (1) Representatives of the press and radio of the US will be permitted to observe fully regarding the utilization of such assistance; and (2) the Government of Turkey will give full and continuous publicity within Turkey as to the purpose, source, character, scope, amounts and progress of such assistance. ${ }^{5}$

5. U.S., Congress, Senate, A Decade of American Foreign Policy, Sen. Doc. No. 123, 81st Cong., 1st sess. (1949), pp. 1265-66. 
Even before the agreement was signed, the State Department had taken two administrative steps to give needed support to PL 75. An Office for the Coordination of Aid to Greece and Turkey was approved. George C. McGhee, who had been Special Assistant to the Under Secretary for Economic Affairs, was appointed the Coordinator.

Loy Henderson, Director for Near Eastern and African Affairs, received approval to add a Division of Greek, Turkish, and Iranian Affairs. John D. Jernegan, who had done much of the spade work during the early planning stage of the program under Henderson, was named the first Chief of the Division.

The Turkish Aid Program ran so smoothly once it got started that most of the problems could be worked out by McGhee and Jernegan and their staffs. This was fortunate for both Henderson and the writer, who succeeded him in July 1948, because of the many pressing problems facing us at the time, such as Palestine, the Arab-Israeli war, and the dispute over Kashmir.

Major General Horace McBride was appointed Director of the army group and got his mission under way in Turkey early in 1948. By the end of October of that year the total military and civilian personnel serving under the Chief of the Mission (the Ambassador) was 374. This had increased to 1364 persons by April 1, 1952.

\section{The military assistance program}

It was clear from the inception of the Truman Doctrine that our aid to Turkey should be directed at modernizing and training the Turkish army. More than five hundred thousand men had been mobilized since early 1940 at great cost to the Turkish economy. But by 1947 this large force was woefully inadequate to cope with the Soviet army. By furnishing the badly needed equip- ment and training, we would make it possible for the Turkish government to devote its resources to the restoration of the national economy. Another urgent need was the construction of all-weather roads which not only would serve to strengthen the military, but would also assist in reviving Turkish agriculture.

These points were forcefully brought out in the messages of the President to Congress supporting the annual bills authorizing continued aid to Greece and Turkey, and by the personal appearance before the Senate Foreign Relations and the House Foreign Affairs Committees of Under Secretary Acheson (who was Acting-Secretary on a number of such occasions and then, from 1949 to 1953, Secretary), our Ambassadors to Turkey, and the Directors of the military aid groups. The importance that both the Democratic and Republican (after January 1953) administrations attached to continued assistance to Greece and Turkey for the entire period of this article is attested by the high level at which attention has been given to it. Their statements may be found in The Public Papers of the President and in the published Hearings of both Committees.

From the beginning of the Truman Doctrine there was a feeling on the part of our Defense officials that funds spent to support the Turkish armed forces accomplished more than aid spent anywhere else. One of the generals just back from Turkey near the beginning of the program told the writer, "A dollar in Turkey is worth two spent on military support anywhere else." Actual experience gained in implementing our aid program in Turkey proved this to be an understatement.

On July 23, 1951, Major General William H. Arnold, Director of the Joint American Military Mission for Assistance to Turkey, told the House Committee that in four years the Mission had 
delivered substantial amounts of military equipment and had trained twentyfive thousand Turkish officers and men in the use of the equipment. Turkey was by far the greatest point of strength in the Middle East. "For your dollar investment you are getting more for your dollars than in any other place. The Turks are fighters. For dollars you get ten Turks for one American for a comparative expense." (The monthly pay of a Turkish soldier at that time, it should be explained, was about twentyone cents.)

Major General George C. Stuart told the House Committee on April 13, 1954, that Turkey had an annual maintenance cost of $\$ 20$ a head, as compared with $\$ 1100$ in Europe and $\$ 3000$ in the United States.

\section{The Marshall Plan and Nato}

The crucial foreign policy decision that the United States would come to the assistance of Greece and Turkey to prevent their succumbing to Soviet pressures having been accepted by Congress, the State Department next turned to the equally urgent problem of assisting Europe to establish a program for its economic rehabilitation. The remarks of Secretary Marshall at Harvard on June 5, 1947, describing this urgency led to the much vaster economic aid program known as the Marshall Plan. The Economic Recovery Act approved April 3, 1948, provided economic aid for Greece and Turkey as well as for Western Europe. Thus the Truman Doctrine, though no less memorable or important, was somewhat overshadowed by the Marshall Plan.

As the Economic Recovery Program was getting under way, the Berlin crisis, arising from the blockade of West Berlin by the Russians, made it clear that the dangers of Soviet aggression were not diminishing. Coming out of this crisis, or at least in part as a result of it, were the North Atlantic Treaty signed in Washington on April 4, 1949, and the North Atlantic Treaty Organization (NATO).

The efforts of the writer and his Office of Near Eastern and African Affairs to have Turkey and Greece included in NATO did not succeed at that time. However, the North Atlantic Council in September 1950 invited them to make arrangements permitting their association "with such appropriate plans for the military planning work of NATO as are concerned with the defense of the Mediterranean." Turkey accepted this invitation on October $2,1950 .^{6}$

In the meanwhile, Turkey, having contributed a brigade of some five thousand men to the U.N. forces in Korea which fought valiantly and suffered heavy casualties, was, with Greece, invited by NATO to become a member in September 1951. The formalities having been completed with the near unanimous vote of the Turkish Grand $\mathrm{Na}$ tional Assembly, Turkey became a member of NATO on February 28, 1952.

So from this time on all appropriations for U.S. military as well as economic assistance were included in appropriations supporting the Mutual Defense Act of 1949. However, the American forces stationed in Turkey under the NATO program were of course separate from the U.S. military and economic aid missions in Turkey.

It is interesting to note in this connection that Ambassador Wilson in a letter dated February 10, 1948, expressed Turkey's concern over Turkey's apparently minor role under the European Recovery Program. In April 1949, shortly after the signing of the North Atlantic Treaty, Turkish Foreign Minister

6. Harry N. Howard, The Development of US Policy in the Near East, 1945-1951 (Department of State Publication 4446), p. 841. 
Necmettin Sadak made an official visit to Washington. At a long meeting with Secretary Acheson, at which the writer was present, the Minister expressed the belief that the exclusion of Turkey from the Atlantic Pact made Turkey seem to its own people as well as to the rest of the world worse off than it had been a year earlier. The Secretary assured the Foreign Minister in reply that Turkey was no less important in U.S. thinking than it had been at the inception of the Turkish Aid Program.

\section{SuCCEsS OF U.S. MilitaRy AND ECONOMIC AID}

The Turkish government and its military forces made the best possible use of the military equipment furnished them on a grant basis and from the training they underwent both in Turkey and the United States. According to many reports, no equipment was discarded-no luxury items were furnished -and nothing went on the scrap heap.

As an indication of the speed with which the program got under way, Secretary Marshall sent a letter to Secretary of the Navy Forrestal as early as February 12, 1948, deploring long delays in the shipment of military supplies to Turkey. He urged the Defense Department to take most urgent action to bring the rate of shipments up to the capacity of the Turkish ports and depots to receive them.

Then on October 1, 1948, our embassy in Ankara telegraphed that the aid program was progressing satisfactorily and had already made sensational progress by Turkish standards.

Before that, on June 5, the Department informed Ankara in a confidential telegram that the value of all Turkish aid under PL 75 for the fiscal year ending June 30, 1948, would be about $\$ 100$ million, of which $\$ 76$ million was for equipment and $\$ 24$ million for expenses.

\section{Turkish Roads Program}

Our roads program, supervised by officials of the U.S. Public Roads Administration, was part of our military aid program. The pressing need for allweather roads for both military and economic reasons was soon determined, and this was one of the first programs started. There were almost no allweather roads in Turkey at the beginning of our aid program, so the writer was often told, because Ataturk had considered the absence of such roads as an important military deterrent, and this was considered of even greater importance once World War II started.

In an article in Foreign Affairs of July 1954, George McGhee, the first Coordinator for Aid to Greece and Turkey who was later Ambassador to Turkey (1951-53) wrote that by the end of 1953 the U.S. government had made a total contribution of $\$ 27,600,000$ toward Turkish road development by providing machinery and experts from our Public Roads Administration. During the same period the Turks, he said, had spent the equivalent of $\$ 293,000,000$ drawn from their own resources on roads, resulting by 1954 in a network of some thirteen thousand miles of all-weather roads.

\section{Economic Assistance Program}

The Economic Assistance Program for Turkey, begun in 1948 under the European Recovery Program, was also very successful. The first head of the mission was Russell H. Dorr, who remained until 1952.

In the area of agriculture, the principal basis of Turkey's economy, the funds furnished made possible the purchase of tractors, plows, combines, and other types of agricultural equipment so that greater areas could be brought under cultivation. The construction of allweather roads also contributed im- 
mensely to an increase in agricultural production.

President Truman in a radio and television address to the American people on March 6, 1952, in giving examples of past successes under the Mutual Security Program, said:

Turkey is another example, where a veritable agricultural revolution is being brought about with a team of nine American experts. ... In three years Turkey has raised its grain production by over 50 per cent and tripled its rice production.

Norman S. Paul, Regional Director for the Near East and Africa of the Foreign Operations Administration, told the House Committee at a hearing on the Mutual Security Act of 1953 on April 13, 1954:

There has been a great deal accomplished in Turkey. Forty per cent more land has been brought into use than was the case before we started. Twenty-five thousand kilometers [15,625 miles] of new roads have been constructed where there were hardly any roads before. They now have four very fine ports where they had none in 1948, and the country generally has achieved a remarkable degree of economic recovery.

The total amount authorized for expenditures in Turkey under the aid programs in the form of grants and loans from July 1, 1948, to June 30, 1955the year Turkey joined the Baghdad Pact-under the pertinent appropriation acts was $\$ 452.8$ million, of which $\$ 195.0$ million was for loans and $\$ 347.8$ million for grants. Total expenditures for that period were $\$ 331.2$ million.

\section{Credits}

After twenty-five years the classified material for the early part of the program, which the writer was authorized to review, does not add much to the material already published; so it has been used sparingly in this article. This is particularly the case because the two highest officials of our government concerned with and responsible for the evolution of the Truman Doctrine have given vivid and authoritative descriptions in their memoirs of their roles in the genesis of the Doctrine. Harry S Truman's will be found in volume 2, Memoirs: Years of Trial and Hope. ${ }^{7}$ Dean Acheson's description of the Doctrine will be found in Present at the Creation: My Years in the State Department. ${ }^{8}$ As will have been noted, both these books have been useful to the preparation of this article.

An interesting and detailed description of the development of the Truman Doctrine may also be found in The Fifteen Weeks (February 21-June 5, 1947) by Joseph Marion Jones. ${ }^{9}$ The author was Press Officer of the Department at the time and was involved in the day-by-day developments at the working level as well as at the top. His book contains very good, and as far as the writer can recall, accurate descriptions of the various offices of the State Department collaborating in the formulation for the President and the Secretary of State of a new foreign policy of unique importance.

Hopefully the 1947 volume of Foreign Relations of the United States containing the as yet unpublished documents pertaining to the Truman Doctrine will also soon appear.

\section{Conclusion}

The Truman Doctrine was indeed a landmark of U.S. foreign policy. Our nation was fortunate that at the crucial period of its inception we had outstand-

7. Truman, Years of Trial and Hope, pp. 93-109.

8. Acheson, Present at the Creation, pp. 217-25.

9. Jones, The Fifteen Weeks, p. 174. 
ing leaders in President Truman, Secretary of State Marshall and Under Secretary Acheson. Although Marshall had passed responsibility for handling this grave problem to Acheson and did not take it back, he gave it his full support from Moscow. A weaker man might have postponed action so displeasing to the Soviet Union until after the Council of Foreign Ministers being held in Moscow had adjourned. Acheson was Acting Secretary during much of the period February 21-May 22, 1947. Acheson in turn gave principal action responsibility to Loy W. Henderson, the exceptionally able Director of the Office of Near Eastern and African Affairs.

Senator Vandenberg, as Chairman of the Senate Foreign Relations Committee and Republican leader of the Senate, played a vital role in persuading his Republican colleagues to support the program for aid to Greece and Turkey on a nonpartisan basis. He also displayed great qualities of leadership. Both the Democratic administration and the Republican Congress under such effective leadership accepted the seriousness of the problem facing our country with the announced withdrawal of British aid to Greece and Turkey, and worked together as a team to develop what came to be known as the Truman Doctrine in a way which assured to the United States the unquestioned leadership of the free world for the next two decades. 